\title{
Global helse - en utfordring for oss alle
}

Det er økende interesse for global helse både her hjemme og ute. Sentre, studier, bøker og artikler om global helse lanseres som aldri før. Politikere, forretningsfolk og kjendiser konkurrerer om å vise det største engasjement. Men vanskelige spørsmål står ubesvart. Hvorfor skal vi hjelpe? Vil mer penger gi bedre resultater? Hvordan skal vi endelig kvitte oss med kolonitidens arv av donor- og mottakerland slik at politikken blir relevant for alle? Hvordan skal vi hindre at de fattige arver våre livsstilssykdommer i tillegg til infeksjonsbyrden?

I samarbeid med redaksjonen i Tidsskriftet har vi koordinert arbeidet med en temaserie om globale helsespørsmål. Serien formidler kunnskap og trekker frem Norges rolle og innsats. Artiklene vil belyse spørsmålene: Hva skjer egentlig innen global helse? Hva og hvor store er helseproblemene i den fattige verden? Hva er de viktigste intervensjoner mot sykdommene som tar millioner av unge liv hvert år? Hva er konsekvensen av at helse er en menneskerettighet? Kan vi tenke oss et regelverk som sikrer fattige mennesker et minimum av helsetjenester? Hvordan er samspillet mellom de ulike aktørene i den globale helsejungelen? Brukes våre midler på best mulig måte? Hvilke problemer har globale styringsmekanismer i forhold til statenes suverenitet?

Helseproblemene i utviklingsland er store, og de har kommet nærmere oss på grunn av globaliseringen. Ikke minst har hiv/aids som en felles global utfordring bidratt til dette. Sarsepidemien og influensapandemiene viser hvordan hele verden direkte blir berørt. Men det er ikke bare direkte sammenhenger - dårlig helse og fattigdom skaper uro og utrygghet, andres sårbarhet er vår sårbarhet, de enkeltes helseutfordringer er alles utfordringer.

Norge ligger i en av verdens mest privilegerte regioner. Vi har hatt flaks. Det er viktig å huske at slik har det bare vært de siste hundre år. Ved inngangen til 1900-tallet døde over $10 \%$ av barna i første leveår. Så sent som i 1938 hadde Norge en spebarnsdødelighet på litt over 50 per 1000 , lik den vi ser i India i dag. Og tallene for død i forbindelse med graviditet og fødsel var enda verre. Så sent som i 1940 døde vel 200 norske kvinner per 100000 i barsel. Det er tall vi i dag finner i Afrika sør for Sahara og i andre fattige land. Og det er altså bare 70 år siden! Tenk om vi kunne overføre den norske fremgangen til andre deler av verden.

Norge er en viktig aktør på den globale helsearenaen. Årelang satsing på bistandsarbeid og helse i den tredje verden gjør at norske synspunkter blir lagt merke til og har innflytelse internasjonalt. «You are punching above your weight class,» er et sitat som er tillagt Hillary Clinton fra et møte med Jonas Gahr Støre. Norge er en tyngre aktør enn hva folketallet skulle tilsi. Dette gjør det mulig for nordmenn å delta aktivt $\mathrm{i}$ utformingen av den fremtidige globale helsepolitikken. Det er for tiden flere sammenfallende forhold som gjør global helse særlig interessant for oss: Statsminister Jens Stoltenberg har vært sentral i oppbyggingen av det globale vaksineinitiativet (GAVI) og i arbeidet med tusenårsmål 4 og 5 (barneog mødrehelse), utenriksminister Jonas Gahr Støre fremmet i 2007 et initiativ for i større grad å involvere helse i utenrikspolitikken, helsedirektør Bjørn-Inge Larsen er siden 2010 representant i styret for Verdens helseorganisasjon.
Vi ser utover. Verden er ikke bare globalisert, men også dynamisk. Institusjoner og problemfelter er i stadig endring. Derfor vil denne serien ikke bringe endelige svar på utfordringene, men forhåpentligvis bidra til bevissthet og forståelse for sammenhenger, noe som igjen kan gi grunnlag for flere artikler på dette feltet i Tidsskriftet.

Vi ønsker å stimulere til økt interesse og diskusjon blant norske leger og medisinstudenter. Global helse er et arbeidsfelt som flere bør være med å forme. Ett mål er å etablere et sterkere nettverk av norske forskere, klinikere, ledere, byråkrater og andre, slik at de bedre kjenner til hverandres arbeid. Dette vil gjøre det lettere for interesserte forskere og praktikere å finne kompetente miljøer innen global helse i Norge. Et annet mål er å skape en felles forståelse av hva som skal til for endring til det bedre. Dermed kan vi opptre samordnet, kunnskapsbasert og reflektert på de mange arenaer ute.

\author{
Harald Siem \\ harald.siem@helsedir.no \\ Just Haffeld \\ Sverre 0. Lie \\ John-Arne Røttingen
}

\begin{abstract}
Harald Siem (f. 1941) er ansatt ved Avdeling for global helse, Helsedirektoratet. Han har vært distriktslege på Aukra, har arbeidet ved Institutt for allmennmedisin ved Universitetet I Oslo, i Oslo helseråd, Arbeidsgiverforeningen og i ti år med internasjonalt helsearbeid i Genève. Ingen oppgitte interessekonflikter.
\end{abstract}

Just Haffeld (f. 1972) er jurist, Master of Negotiation and Conflict Resolution fra Melbourne og sisteårs medisinstudent. Haffeld er tilknyttet O'Neill Institute of National and Global health ved Georgetown University, USA, der han jobber med globale helsespørsmål.

Ingen oppgitte interessekonflikter.

Sverre O. Lie (f. 1938) er ansatt ved Avdeling for global helse, Helsedirektoratet. Han er tidligere klinikksjef og professor ved Barneklinikken, Rikshospitalet. Har de siste fem årene arbeidet med global helse - særlig med Norges engasjement i forhold til FNs tusenårsmål.

Ingen oppgitte interessekonflikter.

John Arne Røttingen (f. 1969) er professor II i helsepolitikk ved Avdeling for helseledelse og helseøkonomi, Institutt for helse og samfunn, Universitetet i Oslo. Tidligere var han direktør i Nasjonalt kunnskapssenter for helsetjenesten, nå er han tilknyttet Harvard School of Public Health og Harvard Kennedy School.

Ingen oppgitte interessekonflikter.

Engelsk oversettelse av hele artikkelen på www.tidsskriftet.no 